\title{
Sığır tüberkülozunda malondialdehit ve superoksit dismutaz'ın immunohisto- kimyasal olarak değerlendirilmesi
}

\author{
Muhammed Mustafa SEZGİNER ${ }^{1}$, Zafer ÖZYILDIZ²
}

${ }^{1}$ Tarım ve Orman Bakanlığı Sandıklı Tarım İl Müdürlügü, Sandıklı, Afyon /TÜRKIYE

${ }^{2}$ Burdur Mehmet Akif Ersoy Üniversitesi Veteriner Fakültesi Patoloji Anabilim Dalı, Burdur/TÜRKIYE

\section{Anahtar Kelimeler: \\ immunohistokimya \\ malondialdehit \\ reaktif oksijen türevleri \\ sı̆̆ır tüberkülozu \\ süperoksit dismutaz}

\section{Key Words:}

immunohistochemistry

malondialdehyde

reactive oxygen species

bovine tuberculosis

superoxide dismutase

Gelis Tarihi: 08.11.2019

Kabul Tarihi: 16.12.2019

Yayın Tarihi: 31.12.2019

Makale Kodu: 644406

\section{Sorumlu Yazar: \\ Z. ÖZYILDIZ \\ (zozyildiz@mehmetakif.edu.tr)}

ORCİD:

MM. SEZGINER: 0000-0001-9812-7605

Z. ÖZYILDIZ: 0000-0002-6009-9191

** Bu Araştırma Burdur Mehmet Akif Ersoy

Üniversitesi Bilimsel Araștırma Projeleri

Koordinatörlüğü tarafindan 0261-YL-15 proje

numarası ile desteklenmiştir. Burdur Mehmet

Akif Ersoy Üniversitesi Sağlık Bilimleri Enstitüsü

Veteriner Patoloji Anabilim Dalı 415111 no'lu

Yüksek Lisans tezinin özetidir.

\begin{abstract}
ÖZ
Sığır tüberkülozu, mücadelenin yetersiz olduğu ülkelerde, önemini koruyan kronik ve zoonoz bir hastalıktır. Çok eski yıllardan beri tanınan bir hastalık olmasına rağmen, klinik tanısı kolaylıkla yapılamamaktadır ve patogenezi tam olarak anlaşılamamıştır. Bu çalışmada, sığır tüberkülozunda, lezyonlu dokularda malondialdehit (MDA) ve süperoksit dismutaz (SOD) aktiviteleri ve bunların hastalığın patogenezi ile ilişkileri incelenmiștir. Bu amaçla, kesimi yapılan, PPD pozitif 25 sığııın lezyonlu iç organlarında SOD ve MDA aktiviteleri immunohistokimyasal olarak değerlendirilmiştir. Çalışmamızın sonucunda, tüberküloz lezyonundaki MDA ve SOD aktivitelerinin özellikle yangısal hücrelerde ve ardından da parankimal hücrelerde arttığı saptanmış ve patogenezde rol oynadıkları kanısına varılmıştır.
\end{abstract}

\section{Immunohistochemical evaluation of malondialdehyde and superoxide dismutase in bovine tuberculosis}

\begin{abstract}
Cattle tuberculosis is an important chronic and zoonotic disease that maintains its importance in countries where struggle is inadequate. Although it has been recognized for many years, its clinical diagnosis cannot be made easily and its pathogenesis is not fully understood. In this study, malondialdehyde (MDA) and superoxide dismutase (SOD) activities in lesioned tissues in bovine tuberculosis and their relationship with the pathogenesis of the disease was investigated. For this purpose, SOD and MDA activities were evaluated immunohistochemically in the internal organs of 25 slaughtered PPD positive cattle. As a result of our study, MDA and SOD activities in tuberculosis lesion increased especially in inflammatory cells and then in parenchymal cells and it was concluded that they play a role in pathogenesis.
\end{abstract}

\section{GİRİ̧}

Tüberküloz (TB), yüzyıllar boyunca insan ve hayvanlanı etkileyen, kronik seyirli, bulaşıcı bir enfeksiyondur. Hastalık lezyonları, paleolitik ve neolitik dönemlere ait kemikler ile eski Misır mumyalarında bulunmuştur $(1,2)$. Sı̆ğır tüberkülozunun etkeni olan Mycobacterium bovis (M.bovis), aside dirençli, aerobik, sporsuz, hareketsiz ve kapsülsüz bir bakteridir (3). İnsan ve hayvanlarda tüberküloza sebep olan mikobakteriler Mycobacterium tuberculosis complex (MTBC) adı altında toplanmıştır (10). Mycobacterium bovis, Karlson ve Lessel tarafindan bu grubun bir üyesi olarak kabul edilmiştir (11). Bakteri ayrıca kendine özgü mikolik asit adı verilen bir madde salg1lar ve mikolik asit hücre yapısı ile hücre duvarının fonksiyonunda kritik bir rol oynar (12). Duyarlı konakçının vücuduna giren $M$. bovis etkenleri girdikleri dokuda yerleşerek yabancı cisim etkisi yapar ve üremeye başlar (13). Daha sonra basile ilk olarak nötrofiller müdahale eder ve etrafinda kümeleşirler. Bu olaydan kısa bir süre sonra nötrofiller degranüle olup karyoreksise uğrar ve yerlerini makrofajlara birakırlar. Etkenler makrofajlar tarafin- dan fagosite edilerek fagozomlara alınırlar. Fagozomlar lizozomal işlemlerini yapmak için phosphotidylinositol 3-phosphate (PI3P) adı verilen bir lipid komplemente ihtiyaç duyarlar. Bu yap1, fagozomların olgunlaşması için gerekli olan bazı proteinlerin oluşmasında rol oynar. Basilden salınan Secreted Acid Phosphatase (SapM) isimli proteinin, PI3P'in defosforilasyonuna sebep olarak fagozomun olgunlaşmasını engellediği belirtilmektedir. Yapılan in vitro bir çalıșmada, mikobakterilerden ekstrakte edilmiş SapM proteinin PI3P'yi hidrolize ederek fagozom sonrası endozomal birleşmeyi inhibe edildiği bildirilmiştir (14). Makrofaj içindeki kontrol edilemeyen çoğalmadan dolayı mikroorganizma lenfatik dolaşım yoluyla bölgesel lenf düğümlerine ve diğer organlara göç edebilir. Basilin açığa çıkardı̆̆ı bazı yapılar sebebiyle makrofajlar şekil değiştirerek sitoplazmaları eozinofilik yapıda olan ve dizilimleri epitel hücrelerine benzeyen epiteloid tipte makrofajlara dönüşürler. Bu hücreler birbirleri ile birleşerek çok çekirdekli ve boyutları 50 mikrona ulaşan dev hücreleri oluştururlar. Bu dev hücreler genellikle Langhans tipi dev hücre olup çekirdek- 
leri hilal şeklindedir ve hücre çeperinin etrafına dizilmişlerdir $(13,15)$. Etkenin ilk girdiği yerde oluşan lezyona primer effekt ad1 verilir. Etkenler aynı organın lenf dügüumlerinde de lezyon oluşturduklarında bu iki lezyona birlikte primer kompleks denir. Her vakada primer effekt olmasına karşın primer kompleks olmayabilir (13). Tüberküloz için karekteristik lezyonlar granülomlardır ve tüberkül olarak adlandırilır. Bu tüberküllerin yapısı fibroblastların arasına gelişigüzel dağılmış lenfositler ve bu yapıyı çevreleyen epiteloid hücreler ile karakterizedir. Tüberkülün yapısı büyüdükçe ortada kalan hücreler kazeifikasyon nekrozuna uğrarlar ve daha sonra bu alanlanda distrofik kalsifikasyon meydana gelir. Lezyon yaşlandıkça etrafını bağ dokusu çevreler ve olgunlaşır. Lezyonlar büyüdükçe etkilenen organlarda kavernler oluşabilir (15).

Sı̆̆ır tüberkülozunun en önemli bulaşma yolu olarak, solunum yolu sekretlerinin bir başka hayvan tarafindan aerojen yolla alınması şeklinde olduğu düşünülmektedir $(1,16)$. Akciğer tüberkülozunda, akciğer, primer lezyonun en çok görüldüğü yerdir. Özellikle de dorso-kaudal bölgelerde, tek veya multiple odaklar şeklinde görülür ve daima bölge lenf dügümlerine yay1lir. Enfeksiyon, bronkopnömonide olduğu gibi bronşio-alveoler bölgelerden başlar ve lobüler yerleşimli, yonca yaprağı görünümünde, multiple odaklar şekillenir. Bazen lezyon akciğerin içerisinde hava yolları veya peribronşial lenfatiklerle yayılabilir. Bu durumda trake ve bronşlarda ülserler ve bronşiektazik kavernler gelişir. Tüberküloz lezyonlan bazen de birbirleriyle birleşerek geniş kazeifikasyon nekroz alanları oluştururlar ki bunlara konglomere lezyonlar denir. Bu lezyonlar diştan bağ dokusuyla veya atelektatik pulmoner parankimle çevrelenmişlerdir. Ayrıca, etkenlerin sayı ve virülensinin yüksek, konakçı direncinin de düşük olduğu durumlarda tüberküloz eksudatif tabiatta düzensiz kazeöz bronkopnömoni veya daha geniş kazeöz lober pnömoni şeklinde görülür (15).

Önemli serbest oksijen radikallerinden olan süperoksit (O2-), hidrojen peroksit (H2O2) ve hidroksil iyonlarının $(\mathrm{OH}-$ ) fosfolipidler ve yağ asitleri ile birleşmeleri sonucu aldehitleri de içine alan çok sayıda peroksidasyon ürünü oluşmaktadır. Bu ürünlerin başlıcalarından olan Malondialdehit (MDA) oksidatif hasar düzeyini göstermede kullanılır $(19,20)$. Lipid peroksidasyonu, normal fizyolojik olaylarda gerçekleşmekle birlikte, viral veya bakteriyel enfeksiyon, ksenobiyotikler, yang1 ve radyosyona maruz kalma gibi durumlarda da dikkati çekmektedir $(21,22)$. Reaktif oksijen türevleri (ROS) sayesinde oluşan lipid peroksidasyonu, hücre membranında hasar meydana getirerek, hücrenin geçirgenliğini etkiler ve hücre içine aşır1 $\mathrm{Ca}^{+2}$ birikmesine neden olarak, hücre membranı disfonksiyonu sonucu hücre şişmesi ve hücre ölümü ile son bulur (23). Kontrol edilemeyen peroksidasyon, membran geçirgenliğini ve permeabilitesini değiştirir. Bu nedenle lipid peroksitler ve MDA gibi ikincil metabolitler dolaşım yoluyla diğer dokularda hasara sebep olabilirler (24).

Doku içinde diğer moleküllerin oksidasyona uğramasını engelleyen moleküllere antioksidanlar adı verilmektedir (28). Antioksidanlar enzimatik ve non enzimatik olmak üzere ikiye ayrilırlar (29). Enzimatik antioksidanlar içinde süperoksit dismutaz (SOD), katalaz, glutatyon peroksidaz (GPx), glutatyon s-transferaz (GST) ve mitokondriyal sitokrom oksidaz enzim- leri yer almaktadır. SOD antioksidan savunma sistemi için primer enzim olup süperoksit radikalini dismutasyonla katalize eden ve iki süperoksit anyonunu moleküler oksijen ile H2O2'e dönüştüren bir metalloproteindir $(25,26)$. Kendi kendine de gerçekleşebilen bu reaksiyon, SOD katalizörlüğünde 4000 kat daha hızlı da gerçekleşebilir (27). Organizma için zararlı olan $\mathrm{H} 2 \mathrm{O} 2$, katalaz ve GPx tarafindan su ve moleküler oksijene dönüştürülmektedir. SOD’un konakçıyı intrasellüler patojenlerden korunmada önemli katkıları olduğu gösterilmiştir $(30,31)$. SOD’un tüm türevlerinin aktivite gösterebilmek için mutlaka bir metal iyonu içermesi gerekmektedir. SOD içerdiği metal iyonu ve aminoasit dizilimleri bakımından iki önemli gruba ayrilmaktadır. Birinci grup bakır ve çinkonun proteinle (CuZnSOD) tamamlanmasindan oluşur. İkinci grupta ise aktif bölgede mangan (MnSOD), demir (FeSODS) ve nadir olarak nikel (NiSOD) bulunur. İkinci grubun birinci grup SOD'dan farkı içerdiği metal iyonu ile aminoasit dizilimindeki farklilıktan kaynaklanır (32). Ekstraselüler matrikste ve intersitisyumda, bakır ile çinko elementi içeren ve ektrasellüler SOD olarak adlandırılan bir süperoksit bulunduğu, bu SOD'un nitrik oksit düzeyini düzenlediği bildirilmiştir (33).

Edinilen literatür bilgilerine göre daha önce $M$. Bovis ile enfekte sığırların lezyonlu dokularında immunohistokimyasal olarak MDA ve SOD reaksiyonları incelenmemiştir. Bu çalışmanin amaci lezyonlu dokulardaki MDA ve SOD immunoreaksiyonlarının incelenerek sığır tüberkülozundaki rollerinin detaylı olarak araştırılmasıdır.

\section{GEREÇ ve YÖNTEM}

\section{Örneklerin toplanmas1}

Çalışmamızın materyalini oluşturan doku örnekleri Afyonkarahisar ili Sandiklı ilçesinde bulunan ve tüberkülin uygulamasına pozitif reaksiyon vermiş olan 4-12 yaş arasındaki 97 baş sı̆̆ırın şartlı kesimi sırasında toplandı. Hayvanların postmortem muayenesinde, makroskobik olarak organlarda tüberküloz lezyonu bulunan veya genaralize tüberküloz olgusuna rastlanan 49 hayvanın 25 tanesinden mediastinal ve bronşiyal lenf yumruları, akciğer, karaciğer ve kalp doku örnekleri alındı. Lezyon görülen hayvanların yaşlarının çoğunlukla 2 yaş altı ya da 6 yaş ve üstü olduğu belirlendi. Bu hayvanların 31 tanesi dişi, 18 tanesi ise erkek olup; lezyon görülen hayvanlardan 27 tanesi Holstein, 11 tanesi Montafon ve 11 tanesi Simental 1rk1 idi. Tüberküloza özgü lezyon bulunan dokular \%10'luk tamponlu formaldehit solüsyonu içinde tespit edildi. Kontrol amacıyla hiçbir makroskobik lezyon göstermeyen 5 sığırın doku örnekleride toplandı. Her bir hayvandan alınan lezyonlu doku örnekleri ayrı kavanozlar içerisine konuldu ve üzerine numune numaralar1 yazılarak Mehmet Akif Ersoy Üniversitesi Veteriner Fakültesi Patoloji Anabilim Dalı'na getirildi.

\section{Histopatolojik yöntem}

Toplanan dokular rutin doku takibinin ardindan parafine gömülerek blokland1. Parafin bloklardan rotary mikrotomla, 5 mikron kalınlığında seri kesitler alınarak hematoksilen eozin (HE), ve Ziehl Neelsen (ZN) boyama yöntemleri ile boyarak 1ş1k mikroskobunda incelendi. 
İmmunohistokimyasal yöntem

Parafin bloklardan Poly-L-lizin ile kaplanmış adeziv lamlara kesitler alınd1. Streptoavidin-biotin kompleks peroksidaz yöntemi (ABC-P) ile yapılan immunhistokimyasal boyamada, SOD [Anti-SOD2 antibody (ab13533), Abcam, 1/100 dilüsyon] ve MDA [Anti-Malondialdehyde antibody (ab6463)), Abcam, 1/100 dilüsyon] markırlarının reaksiyonu ticari immunoperoksidaz kiti (Invitrogen) ile ortaya kondu. Kromojen olarak DAB (3,3 diaminobenzidine) kullanıldı ve zemin boyama Harris hematoksilen ile yapılarak preparatlar 1 ş1k mikroskobunda incelendi.

\section{BULGULAR}

\section{Makroskobik bulgular}

Hayvanların mezbahada şartlı kesimi sonrasında yapılan postmortem muayenede tüberküloz lezyonlarının en sık olarak mediastinal lenf yumruları ve akciğerlerde lokalize olduğu gözlendi. Makroskobik lezyonlar sert kıvamlı olup yapılan kesitler sırasında kalsifikasyondan dolayı çıtırtı sesi duyuldu. Yapılan postmortem muayene sonucu 25 hayvanin 3 tanesinde generalize tüberküloz olgusuna rastland1. Generalize tüberküloz olgularından birinde kalp dokusunda da tüberküloz lezyonu saptand1. Diğer generalize tüberküloz olgularda ise periton, plöra, akciğger, karaciğer ve toraksın iç yüzlerinde tüberküller belirlendi (Şekil 1.A).

Bazı havvanlarda tek tük odaklar halinde olan tüberküllerin bazı hayvanlarda yayg1n şekilde olduğu, hatta birleşerek konglomere tüberkülleri oluşturdukları dikkati çekti. Şekillenen lezyonların büyüklüğü genellikle birbirine yakın olmakla birlikte

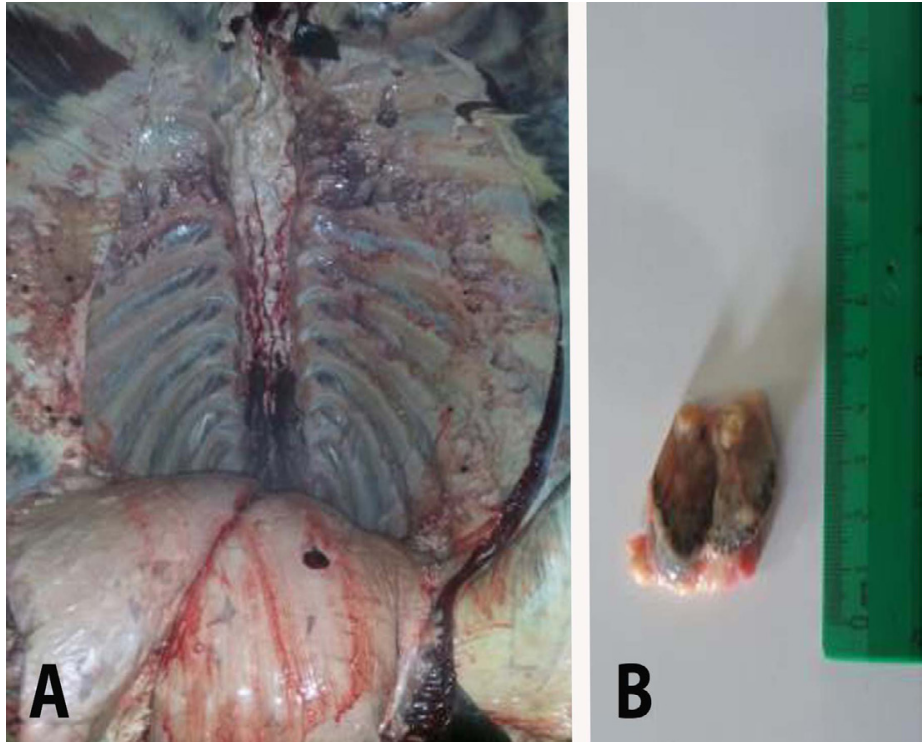

Şekil 1 A. Sı̆̆ır, generalize tüberküloz, kostaların iç yüzü ve peritonda yaygın ve multiple tüberküller, B. Sı̆̆ır, mediastinal lenf yumrusu, tipik tüberküller

bazı hayvanlarda değişik büyüklükte tüberküllerin oluştuğu saptandi. Generalize tüberküloz dişındaki olguların tamamına yakın kısmında akciğer ve mediastinal lenf yumrularında tüberküloz lezyonları hakimdi (Şekil 1.B). Sadece 4 olguda karaciğerde tüberküller saptand1.

\section{Mikroskobik bulgular}

Mikroskobik incelemelerde, kontrol olarak alınan dokularda herhangi bir lezyona rastlanmadı (Şekil 2. 1A, 2A, 3A). Tüberkülozlu akciğer (Şekil 2.1B), karaciğer (Şekil 2.2B) ve lenf dügüumlerinde (Şekil 2.3B) ise tipik granülom yapılarına rastlandı.
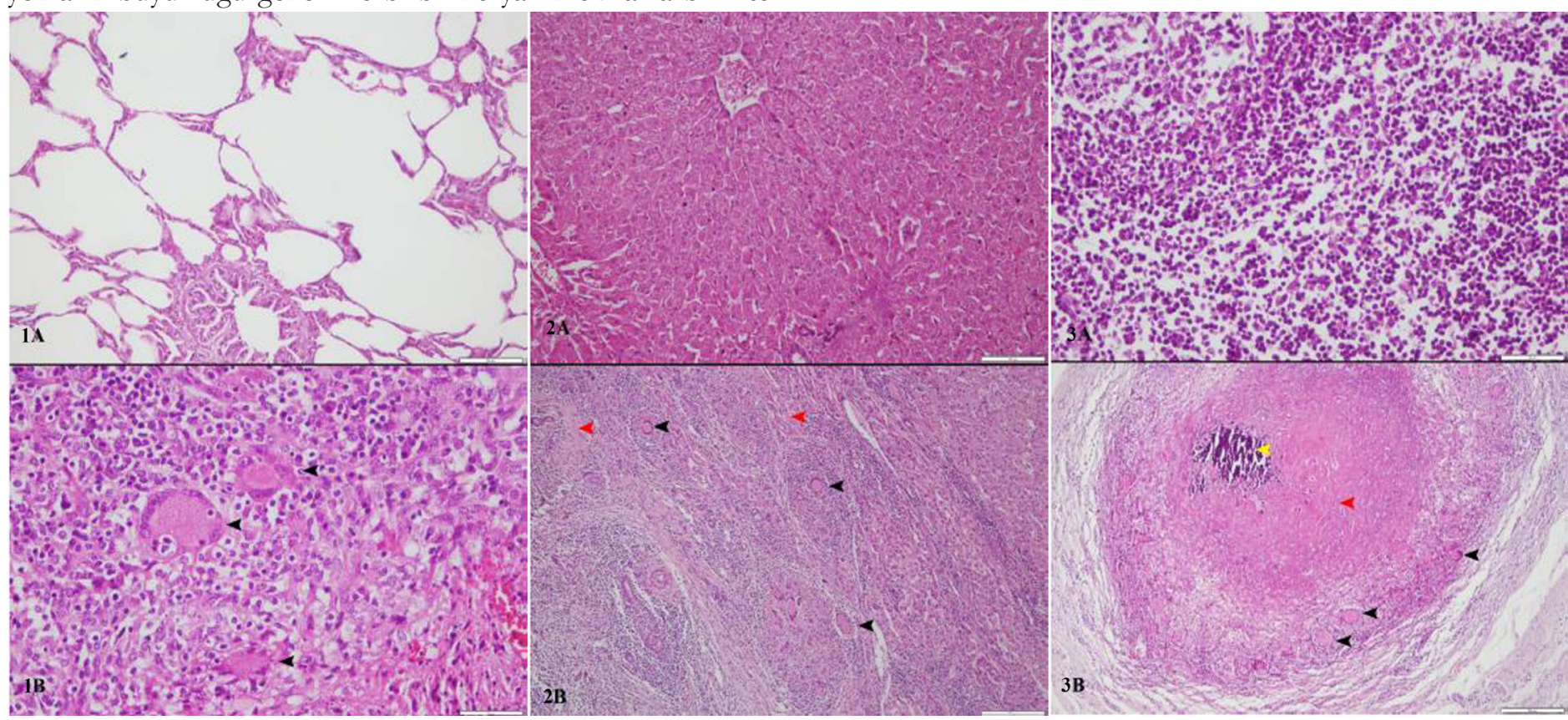

Şekil 2 1A) Sı̆̆ır, kontrol grubu, akciğer, normal histolojik görünüm, HE, Bar= $200 \mu$ m 1B) Siğır, akciğer, plöra üzerinde şekillenmiş tipik bir tüberkülün yakından görünümü, Langhans tipi dev hücreler (ok başları), HE, Bar=100 $\mu$ m, 2A) Sığır, kontrol grubu, karaciğer, normal histolojik görünüm, HE, Bar= $100 \mu \mathrm{m}$. 2B) S1 ̆ı1r, karaciğer, tüberküllerin görünümü (k1rmız1 ok başları), Langhans tipi dev hücreler (siyah ok başları), HE, Bar=200 $\mu \mathrm{m}$. 3A) Sı̆̆ır, kontrol grubu, mediastinal lenf dügüumü, normal histolojik görünüm, $\mathrm{HE}, \mathrm{Bar}=50 \mu \mathrm{m}, 3 \mathrm{~B}) \mathrm{S} 1 \mathrm{ğ} 1 \mathrm{r}$, mediastinal lenf düğümü, lenf düğümündeki bir granülomun görünümü, Langhans tipi dev hücreler (siyah ok başları), kazeifikasyon nekrozu (kırmızı ok başı) ve kalsifikasyon alanı (sarı ok başı), HE, Bar= $200 \mu \mathrm{m}$. 

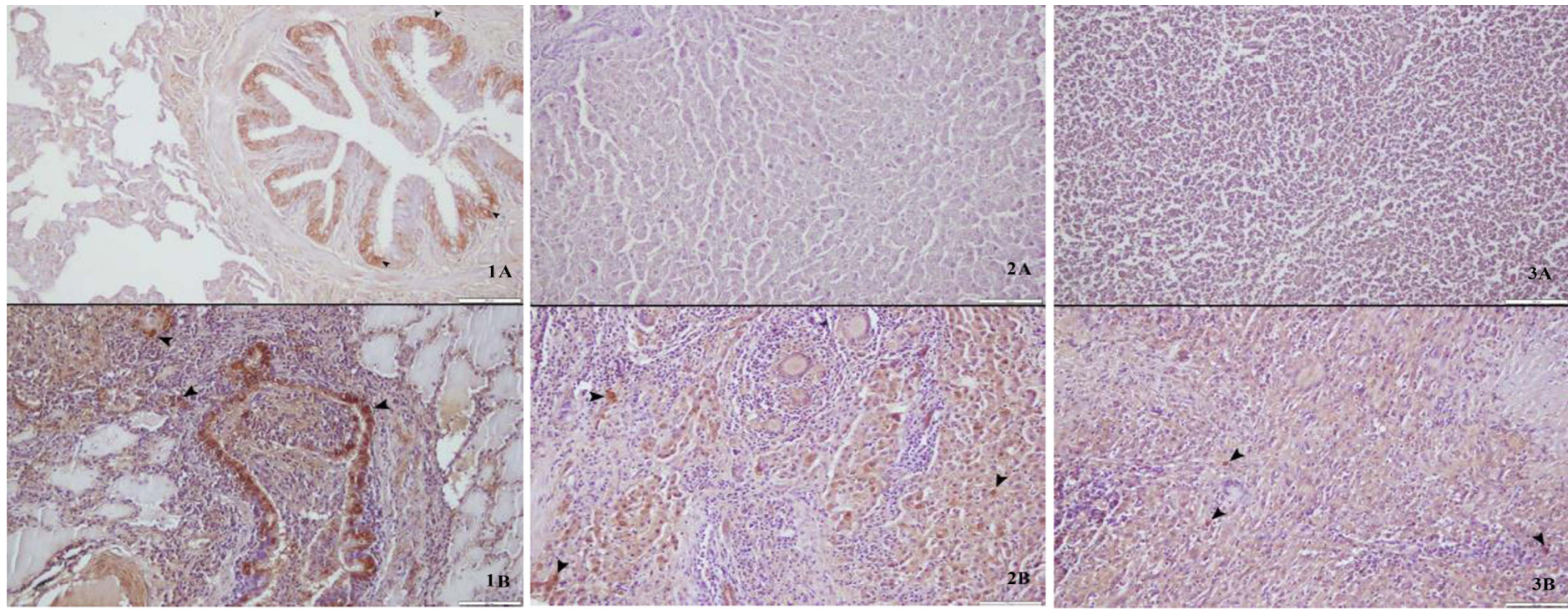

Sekil 3 Farklı organlarda SOD immunoreaktivitesi, ABC-P yöntemi, DAB kromojen, Harris hematoksilen zemin boyama. 1A) S’ğır, kontrol grubu, akciğer, bronşioler epitelde hafif pozitif reaksiyon (ok başları), Bar= $200 \mu \mathrm{m}$. 1B) Sı̆̆ır, akciğer, tüberküloz, bronşioler epitelde artmış immunoreaktivite (okbaşları), Bar=100 $\mu \mathrm{m}$. 2A) Sı̆̆ır, kontrol grubu, karaciğer, normal karaciğer

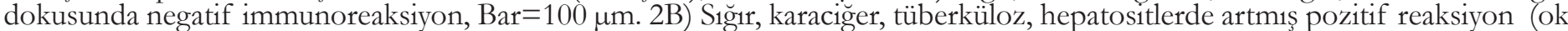

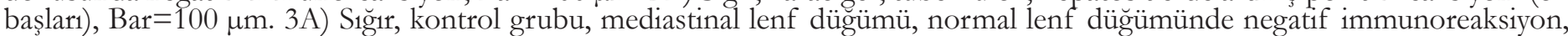

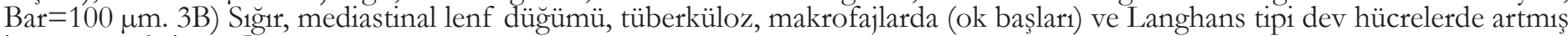
immunoreaksiyon, Bar $=100 \mu \mathrm{m}$.
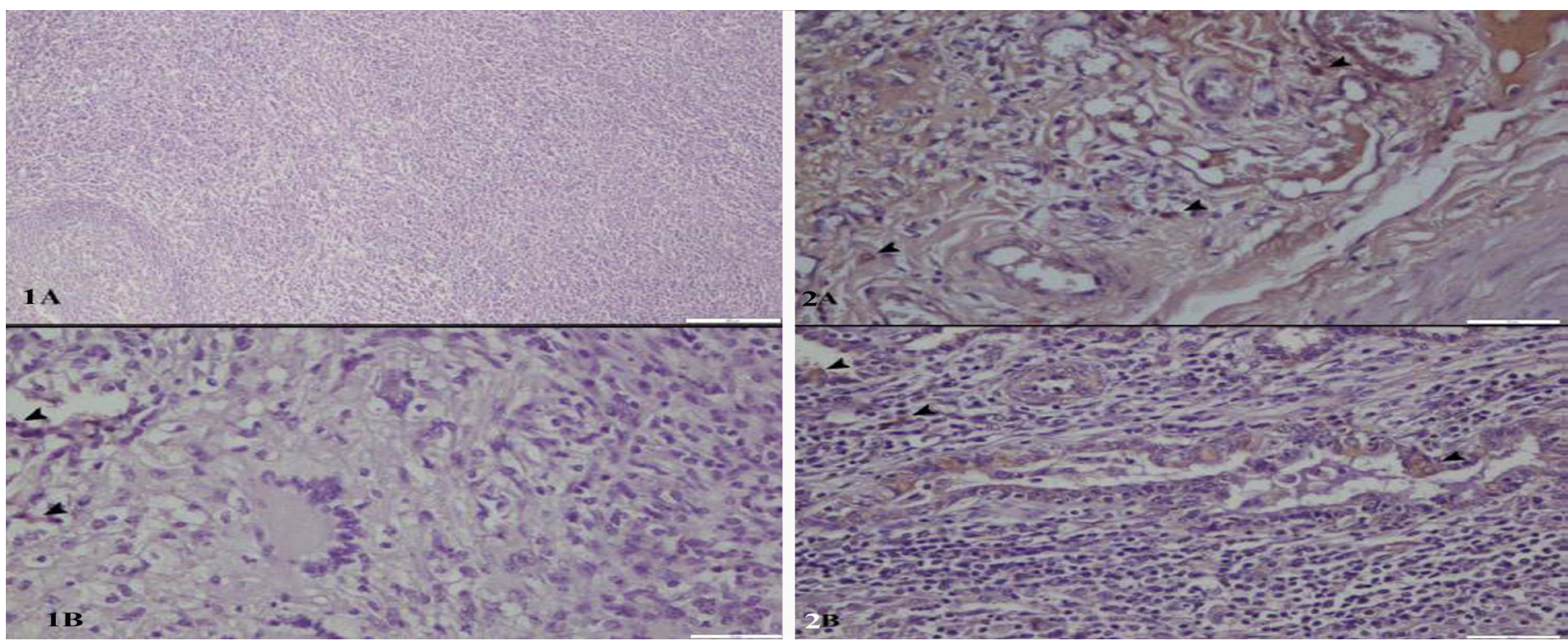

Şekil 4 Farklı organlarda MDA immunoreaktivitesi, ABC-P yöntemi, DAB kromojen, Harris hematoksilen zemin boyama. 1A) Sığır, kontrol grubu, mediastinal lenf düğümü, normal lenf düğümünde negatif immunoreaksiyon, Bar=200um. 1B) S1ğır, mediastinal lenf düğümü, tüberküloz, lenf düğümündeki lezyonlu bölgede pozitif immunoreaksiyon (ok başlari), Bar=50 $\mu$ m.

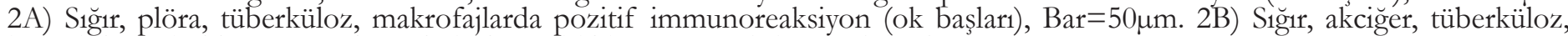
bronşioler epitelde ve yang1 hücrelerinde pozitif immunoreaksiyon (ok başları), Bar=50 $\mu$ m.

Dokularda görülen granülom yapılarının merkezlerinde kalsifikasyon, etrafindaki hücrelerde kazeifikasyon nekrozu ile bunlar1 çevreleyen alanlarda lenfosit, makrofaj, epiteloid hücreler ve Langhans tipi dev hücreleri ve bazı alanlarda fibroblast ve fibrositler gözlendi (Şekil 2. 1B, 2B, 3B).

Mikobakterilerin saptanması için lezyonlu alanlardan alınan kesitlerin Ziehl-Neelsen boyama yöntemiyle boyanması ile tüberküloz basilleri mavi zemin üzerinde kırmızı çomaklar şeklinde görüldü.

\section{İmmunohistokimyasal bulgular}

\section{SOD immunoreaktivitesi}

Sunulan çalışmada, SOD markırı ile immunohistokimyasal olarak boyanan kesitlerin incelenmesinde kontrol grubunda bulunan hayvanlara ait akciğer dokularının sadece bronşiol epitellerinde hafif pozitiflik görüldü (Şekil 3.1A) Kontrol grubunun diğer doku ve organlarında ise SOD markırı ile immunopozitif reaksiyon gözlenmedi (Şekil 3.2A, 3A). SOD immunoreaktivitesinin tüberküloz lezyonu bulunan dokularda 
belirgin şekilde arttığ1 gözlendi. Akciğer, karaciğer ve lenf yumrusunda özellikle makrofajlar, epiteloid hücreler ve Langhans tipi dev hücrelerde immunopozitiflik belirgindi (Şekil 3.1B, 2B, 3B). Ayrıca tüberküloz lezyonu bulunan akciğer dokuları, kontrol grubu akciğer dokularıyla karşılaştırıldığında bronşiyollerin epitel hücrelerinde bulunan pozitifliğin belirgin şekilde arttı̆̆1 dikkati çekti (Şekil 3.1B). Normal karaciğerde saptanmayan SOD aktivitesi tüberkülozlu karaciğerlerde yoğun şekilde gözlendi. Karaciğgerde granülomlara yakın bölgelerde bulunan hepatositlerde SOD aktivitesinin daha yüksek olduğu, granülomlardan uzak bölgelerindeki hepatositlerde ise SOD aktivitesinin azaldığı saptandı.

\section{MDA immonoreaktivitesi}

Kontrol grubundan alınan doku örneklerinde negatif MDA aktivitesi görüldü (Şekil 4.1A). Bununla birlikte, MDA aktivitesinin tüberküloz lezyonlarında arttığı saptandı. Ancak bu artışın hafiften orta şiddette kadar değişen derecelerde olduğu dikkati çekti. Tüberküloz lezyonlarının bulunduğu dokulardaki yang1sal hücrelerde, özellikle makrofajlarda immunopozitiflik belirlendi (Şekil 4. 1B, 2A, 2B). Akciğerde lezyonlu bölgedeki bronşiyol epitellerinde de MDA aktivitesinin bulunduğu saptandi.

\section{TARTIŞMA ve SONUÇ}

Tüberküloz enfeksiyounda bulaşma ve immun sistem yetersizliği lezyonların şiddeti ve görülme sıklığında önemli kriterlerdendir. İmmun sitemi yeterince gelişmeyen veya ileri yaşlarla beraber immun sistemi zayıflayan hayvanlarda oldukça fazla görülür. Genellikle aerogen ya da alimenter bulaşma gözlenmesine rağmen, süt ve transplasental yolla da bulaşabilmektedir $(3,10)$. Sunulan çalışmada tüberkülin pozitif 97 hayvandan 49 tanesinde makroskobik ve mikroskobik lezyonlara rastlanmıştır. Lezyonlara rastlanan hayvanların genellikle çok genç ya da çok yaşlı hayvanlarda görülmesi hastalığın immun sistem yetersizliği durumlarında şiddetli lezyonlar görülmesini doğrular nitelikteydi. Bununla birlikte 2 yaşın altındaki hayvanlarda sıklıkla görülmesi bulaşmanın transplasental ya da süt yoluyla oldukça etkin bir biçimde olduğunu, enfekte hayvan sütlerinin ciddi bir bulaşma yolu olduğunu ön plana çıkarmakta ve insan sağlığ1 için ne kadar büyük bir tehlike olduğunu vurgulamaktadır. Holstein 1rkı sığırlarda daha fazla görülmesinin nedeninin ise Türkiye'de süt sı̆̆ırı yetiştiriciliğinde çoğunlukla holstein 1rk1 sığırların tercih edilmesine bağlanmıştır.

Sı̆̆ır tüberkülozunun teşhisinin doğru yapılması ve kontrol yöntemlerinin geliștirilmesi için patogenezin tam olarak anlaşılması önemli bir noktadır (35). Günümüzde s1ğ1r tüberkülozunun antemortem teşhisi amaciyla PPD ve IFN- $\gamma$ testleri kullanılmakta olup (18), bu testlerin duyarlilık ve spesifitelerinin kesin tanıya götürmediği bildirilmektedir (36). Ülkemizde ve birçok ülkede intradermal tüberkülin testi ile reaktif hayvanların kesilmesi suretiyle başarılı bir sığır tüberkülozu kontrolü sağlanmaktadır. Buna karşın bazı araştırıcılar bu kontrol yönteminin yetersiz kaldığını ve yeni teşhis yöntemlerinin geliştirilmesi gerektiğini düşünmektedirler (35). Sunulan çalışmada sığır tüberkülozunun patogenezinin anlaşılması amacıyla SOD ve MDA aktiviteleri tüberküloz lezyonlarında immunohistokimyasal olarak incelenmiş ve sı̆̆ır tüberkülozunun patogenezinde bu markırların etkisi araştırılmiştır.

Yapılan çalışmaların birçoğunda sı̆̆ır tüberkülozunun en fazla akciğer dokusunu ve onu drene eden mediastinal lenf yumrularını etkilediği bildirilmiş olup $(1,37,38)$, sunulan çalışmada da materyal olarak kullanılan tüm hayvanların akciğer ve mediastinal lenf yumrularında tüberküloz lezyonları saptanmıştır. Bu bulgu önceki çalışmalar ile uyumlu bulunmuş ve solunum yolu ile şekillenen hastalığın en s1k akciğerleri etkilediğini göstermiştir. Çalışmada ayrıca karaciğer ve dalakta da lezyonlara rastlanmıştır. Bir olgumuzda ise kalp dokusunda tüberküloz lezyonu görülmüştür. Bu da hastalığın kronikleştikçe birçok doku ve organda lezyon oluşturma kapasitesini ortaya koymuştur.

Sığ1r tüberkülozunda serum veya doku MDA seviyelerinin biyokimyasal seviyeleri hakkinda herhangi bir bilgi bulunmamaktadir. Palanisamy ve ark. (39), Mycobacterium tuberculosis ile deneysel enfekte kobayların akciğer dokularında MDA varlı̆̆ını immunohistokimyasal olarak incelemişler ve sağlıklı hayvanlardaki çok zayıf veya negatif sonuçlara karşın, MDA varlığının en fazla granülomların olduğu bölgelerdeki makrofajlar, damar endotel hücreleri ve granülositlerde görüldügünü bildirmişlerdir. Sunulan bu çalışmada, kontrol grubu sağlıklı hayvanların dokularında herhangi bir MDA aktivitesi görülmemesine rağmen, lezyonlu dokularda, granülom yapısında bulunan makrofajlarda ve yangısal hücrelerde belirgin şekilde artmış immunopozitiflik görülmüş ve yapılan önceki çalışma ile paralellik saptanmıştır. MDA seviyesinin enfekte hayvanların dokularında artışının konakçının immun sisteminin etkeni yok etmek amacıyla immun hücrelerinin üretmiş oldukları ROS’lar sebebiyle olduğu düşünülmektedir. MDA'nın özellikle tüberküloz tespit edilen sürülerde diğer hayvanların da enfekte olup olmadıklarının tespitinde bir kriter olabileceği düşünülmektedir. Ancak bu konunun kesinleştirilmesi için tüberkülozlu sığırlarda serum ve doku MDA aktivitesinin birlikte inceleneceği çalışmalara ihtiyaç bulunmaktadır. Sunulan çalışmada, MDA'nın sığır tüberkülozunun patogenezinde etkili olduğunu gösteren öncü bir çalışma olarak değerlendirilmektedir.

Pek çok aerobik organizma normal metabolizma ve stres durumlarında süperoksit, $\mathrm{H}_{2} \mathrm{O}_{2}$ ve hidroksil radikalleri gibi ROS'lara maruz kalmaktadır. Canlıların ROS'lara karşı kompleks savunma ve tamir sistemleri bulunmaktadır. SOD, süperoksit anyonunu aktif bölgesinde içerdiği metal iyonu ile katalize ederek oksijen ve $\mathrm{H}_{2} \mathrm{O}_{2}$ "ye çeviren, oksidatif savunma sisteminin önemli bir enzimidir $(40,41,42)$. Lakari ve ark. (33), normal akciğer dokusunda bulunan bronşiyollerde CuZnSOD'a karşı immunopozitiflik saptandığını bildirmişlerdir. Sunulan çalışmada da normal akciğer dokularında bronşiyol epitellerinde hafiften orta şiddette SOD immunopozitif reaksiyonlar gözlendi. Kontrol grubuna ait sağlıklı karaciğer ve lenf dokularında ise SOD negatif immunoreaksiyonlar mevcuttu. Bununla birlikte tüberküloz lezyonlu dokularda SOD aktivitesinin artmış olduğu ve bu aktivitenin Langhans tipi dev hücreler, epiteloid hücreler ve makrofajların bulunduğu alanlarda yoğunlaştığ1 tespit edildi. Böylece sağl1klı akciğer dokusundaki bronşiyollerde gözlenen immunopozitifliğin, tüberkülozlu akciğer dokusundaki bronşiyollerde belirgin şekilde arttığı da 
gözlendi. Yine bu çalışmada granülomlarda yoğun immunopozitifliğin varlı̆̆ dikkati çekmiştir. Dokularda oluşan lezyonlara yakın bölgelerdeki parankim hücrelerinde immunopozitifliğin daha fazla olduğu ve sağlam doku ve hücrelerin lezyondan uzaklaştıkça aktivitelerinin azaldığı gözlendi. Bu çalışma sonucu dokularda gözlenen artmıs SOD aktivitesinin immun sistem hücreleri tarafindan salg1lanan ROS'ların zararlı etkilerini kompanze etmek amaciyla şekillendiği düşünülmüştür. Bu çalışma sığır tüberkülozunun patogenezinde SOD'ın önemli bir rol oynadığını göstermiştir. Hastalığın klinik tanısında SOD’ın kullanılıp kullanılamayacağının belirlenmesi için yeni çalışmalara ihtiyaç vardir.

Yapılan literatür taramaları 1şı̆̆ında günümüze kadar sığır tüberkülozunun patogenezisinin tam olarak anlaşılmadığ1 görülmektedir. Bu çalışma ile SOD ve MDA aktivitelerinin tüberküloz lezyonu bulunan dokuların parankiminde ve yang1 hücrelerinde immunohistokimyasal olarak arttı̆̆1 görülmüş ve sığır tüberkülozunun patogenezinde ROT'nin önemli bir rolü olduğu ortaya konmuştur.

\section{KAYNAKLAR}

1. Francis J. Tuberculosis in Animals and Man: A study in Comparative Pathology. 13th ed. London: Cassel and Co.; 1958. p. 357.

2. Steele JH, Ranney AF. Animal tuberculosis. Am Rev Tuberc. 1958; 77:908-922.

3. Özbey Ö, Kalender H, Muz A. Siğır Tüberkülozu'nun Epidemiyolojisi ve Teşhisi. FÜ Sağ Bil Derg. 2008; 22:307-314. 4. Feng Z, Hu W, Marnett LJ, Tang M. Malondialdehyde, a major endogenous lipid peroxidation product, sensitizes human cells to UV- and BPDE-induced killing and mutagenesis through inhibition of nucleotide excision repair. Mutat Res. 2006; 601:125-136.

5. Gök M, Yapıc1 İ, Uzun K,Erdem S, Ünlü A, Büyükbaş S. Aktif tüberküloz hastalarında total antioksidan kapasitesi ve malondialdehit (MDA) seviyeleri. TAD. 2006; 4:22-24.

6. Kaklıkkaya I, Menteşe Ü, Koramaz I, Altun G, Menteşe A, Çakıroğlu Y et al. Deneysel iskemi reperfüzyon modelinde, etil pirüvat uygulamasının sonuçları. Turkish J Thorac Cardiovasc Surg. 2010; 18:310-314.

7. Beauchamp C, Fridovich I. Superoxide Dismutase: Improved Assays and an Assay Applicable to Acrylamide Gels. Anal Biochem. 1971; 44:276-287.

8. McCord JM, Fridovich I. Superoxide dismutase: the first twenty years (1968-1988). Free Raid Biol Med. 1988; 5:363369.

9. Lavelle F, McAdam ME, Fielden EM, Roberts PB. A pulse-radiolysis study of the catalytic mechanism of the ironcontaining superoxide dismutase from Photobacterium leiognathi. Biochem J. 1977; 161:3-11.

10. Milli ÜH, Hazıroğlu R. Tüberkuloz. Veteriner Patoloji, 2. bask1. Medipres, Malatya. 2001; 87-97.

11. Karlson AG, Lessel EF. Mycobacterium bovis nom. nov. Int J Syst Evol Microbiol. 1970; 20:273-282.

12. Barry CE III, Lee RE, Mdluli K, Sampson AE, Schroeder BG, Slayden RA et al. Mycolic acids: structure, biosynthesis and physiological functions. Prog Lipid Res. 1998; 37:143-179.
13. Gürel A. Tüberkülozis. http://www.vetder.org/ tuberculozis.html. 2014. Erişim tarihi: 07.12.2014.

14. Puri RV, Reddy PV, Tyagi AK. Secreted Acid Phosphatase (SapM) of Mycobacterium tuberculosis Is Indispensable for Arresting Phagosomal Maturation and Growth of the Pathogen in Guinea Pig Tissues. Plos one. 2013; 8: 1-12.

15. Jones TC, Hunt RD, King NW. Veterinary Pathology. 6th ed. Maryland: Lippincott Williams and Wilkins; 1997. p: 490497.

16. Morris RS, Pfeiffer DU, Jackson R. The epidemiology of Mycobacterium bovis infections. Vet Microbiol. 1994; 40: 153-177. 17. Ortatatlı M, Çiftçi MK, Tuzcu M. Sı̆̆ırlarda Tüberküloz ve Diğer Granülomatöz Pnömoniler Üzerine Patolojik Incelemeler. Vet Bil Derg. 1998; 14: 139-150.

18. Sayın Z, Erganiş O. Sığır Tüberkülozunun Teşhisinde Kullanilan Metotlar. Kocatepe Vet Derg. 2010; 3: 77-82.

19. Nielsen F, Mikkelsen BB, Nielsen JB, Andersen HR, Grandjean P. Plasma malondialdehyde as biomarker for oxidative stress: reference interval and effects of life-style factors. Clin Chem. 1997; 43: 1209-1214.

20. Okutan H, Savas C, Delibas N. The antioxidant effect of melatonin in lung injury after aortic occlusion-reperfusion. Interact Cardiovasc Thorac Surg. 2004; 3: 519-522.

21. Bartsch H. Keynote address: exocyclic adducts as new risk markers for DNA damage in man. IARC Sci Publ. 1999; 150: $1-16$.

22. Esterbauer H, Schaur RJ, Zollner H. Chemistry and biochemistry of 4-hydroxynonenal, malonaldehyde and related aldehydes. Free Radic Biol Med. 1991; 11: 81-128.

23. Kaçmaz A, Polat A, User Y, Tilki M, Özkan S, Şener G. Octreotide improves reperfusion-induced oxidative injury in acute abdominal hypertension in rats. J Gastrointest Surg. 2004; 8: 113-119.

24. Suhail M, Suhail S, Gupta BK, Bharat V. Malondialdehyde and Antioxidant Enzymes in Maternal and Cord Blood, and their Correlation in Normotensive and Preeclamptic Women. J Clin Med Res. 2009; 1: 150-157.

25. Fridovich I. Superoxide dismutases. Annu Rev Biochem. 1975; 44: 147-159.

26. Mann T, Keilin D. Haemocuprein and Hepatocuprein, Copper-Protein Compounds of Blood and Liver in Mammals. Proc Roy Soc. 1938; 126: 303-315.

27. Akkuş I (1995): Serbest radikaller ve fizyopatolojik etkileri. Konya: Mimoza yayınlar1; 1995. p. 38.

28. Sies H. Oxidative stress: oxidants and antioxidants. Exp Physiol. 1997; 82: 291-295.

29. Sharma P, Jha AB, Dubey RS, Pessarakli M. Reactive Oxygen Species, Oxidative Damage, and Antioxidative Defense Mechanism in Plants under Stressful Conditions. J of Bot. 2012; 1-26.

30. Özel GSK, Birdane YO (2014): Antioksidanlar. Kocatepe Vet J. 2014; 7: 41-52.

31. Beaman, L. Beaman, BL. Monoclonal antibodies demonstrate that superoxide dismutase contributes to protection of Norcardia asteroides within intact host. Infect Immunol. 1990; 58: 3122-3128.

32. Gutteridge, J. M. C. (1977). The protective action of superoxide dismutase on metal-ion catalysed peroxidation of phospholipids. Biochemical and Biophysical Research Com- 
munications, 77(1), 379-386.

33. Lakari E. Expression of oxidant and antioxidant enzymes in human lung and interstitial lung diseases. Oulu Uni Press, 2002; 1-86.

34. Ramos-Vara JA, Miller MA. When Tissue Antigens and Antibodies Get Along: Revisiting the Technical Aspects of Immunohistochemistry: The Red, Brown, and Blue Technique. Vet Pathol. 2014; 5: 42-87.

35. Andersen, P., Munk, M., Pollock, J., \& Doherty, T. (2000). Specific immune-based diagnosis of tuberculosis. The Lancet, 356(9235), 1099-1104.

36. Bezos J, Casal C, Romero B, Schroeder B, Hardegger R, Raeber AJ, Lopez L, Rueda P, Dominguez L. Current antemortem techniques for diagnosis of bovine tuberculosis. Res Vet Sci. 2014; 97: 544-552.

37. Beytut E. Kars İli ve Yöresinde Sığırlarda Tüberküloz İnsidensi ve Lezyonların Lokalizasyonu Üzerine Patolojik İncelemeler. Kafkas Üniv Vet Fak Derg. 2001; 7: 15-25.

38. Morris RS, Pfeiffer DU, Jackson R. The epidemiology of Mycobacterium bovis infections. Vet Microbiol. 1994; 40: 153-177. 39. Palanisamy GS, Kirk NM, Ackart DF, Shanley CA, Orme IM, Basaraba RJ. Evidence for oxidative stress and defective antioxidant response in guinea pigs with tuberculosis. PLos One. 2011; 6: e26254.

40. Kanth BK, Oh T, Sohng JK. Identification of two superoxide dismutases (FeSOD and NiSOD) from Streptomyces peucetius ATCC 27952. Biotech and Bioproc E. 2010;15: 785792.

41. Gassó D, Vicente J, Mentaberre G, Soriguer R, Rodriguez RJ, Navarro-González N, Tvarijonaviciute A, Lavín S, Fernández-Llario P, Segalés J, Serrano E. Oxidative stress in wild boars naturally and experimentally infected with Mycobacterium bovis. PloS one, 2016; 11(9), e0163971.

42. Wu T, Bai H, Zhao Z, Wang M, Hu X, Jiao L, Wu Q, Liu T, Zhang C, Chen H, Zhang J, Song J, Wu L, Zhou W, Tong $\underline{C}$, Ying B. A prospective study on associations between superoxide dismutase gene polymorphisms and antituberculosis drug-induced liver injury in a Chinese Han population. The Journal of Gene Medicine, 2019; 21(10), e3121. 